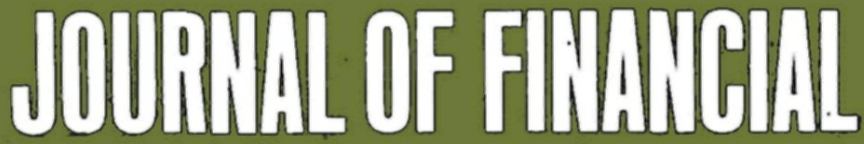 AND QUANIIIATINE AWALYOSOS
}

\section{September 1973}

CLEMENT G. KROUSE and WAYNE Y. LEE

Optimal Equity Financing of the Corporation

\section{RICHARD W. MCENALLY}

Some Portfolio-Relevant Risk Characteristics

of Long-Term Marketable Securities

\section{R. BURR PORTER}

An Empirical Comparison of Stochastic Dominance and Mean-Variance Portfolio Choice Criteria

\section{RONALD J. JORDAN}

An Empirical Investigation of the Adjustment of Stock Prices to New Quarterly Earnings Information

\section{BERNELL K. STONE}

A Linear Programming Formulation of the General Portfolio Selection Problem

ALAN S. MCCALL and DAVID A. WALKER The Effects of Control Status on Commercial Bank Profitability

R. CHARLES MOYER and EDWARD SUSSNA Registered Bank Holding Company Acquisitions:

$$
\text { A Cross-Section Analysis }
$$

RICHARD H. PETTWAY

Integer Programming in Capital Budgeting:

A Note on Computational Experience

BENTON E. GUP

A Note on Stock Market Indicators and Stock Prices

\section{CLOVIS DE FARO}

A Sufficient Condition for a Unique

Nonnegative Internal Rate of Return: A Comment

SURESH P. SETHI

A Note on Modeling Simple Dynamic

Cash Balance Problems 
JOURNAL OF FINANCIAL AND QUANTITATIVE ANALYSIS

\author{
A JOINT PUBLICATION \\ OF THE \\ GRADUATE SCHOOL OF BUSINESS ADMINISTRATION \\ UNIVERSITY OF WASHINGTON \\ AND THE \\ WESTERN FINANCE ASSOCIATION
}

EDITORIAL STAFF

Charles W. Haley, Managing Editor

Nancy L. Jacob, Associate Managing Editor

Lynn Lewicki, Editorial Associate

BOARD OF EDITORS

Charles $\mathrm{w}$. Haley, Washington

Fred P. Morrisey, UC, Berkeley

Edward W. Reed, U.S. National Bank of Oregon

Ezra Solomon, Stanford

J. Fred Weston, UCLA

ASSOCIATE EDITORS

Richard H. Bernhard, North Carolina state Marshall E. Blume, Pennsylvania

Charles P. Bonini, Stanford Richard S. Bower, Dartmouth William Breen, Northwestern Michael J. Brennan, UBC Myles Delano, Michigan State Thomas R. Dyckman, Cornell Peter A. Frost, Washington Robert C. Goshay, UC, Berkeley Nils H. Hakansson, UC, Berkeley Robert S. Hamada, Chicago Warren H. Hausman, MIT Frank C. Jen, SUNY, Buffalo
Michael C. Jensen, Rochester George Kaufman, Oregon Alan Kraus, Stanford Henry A. Latané, North Carolina John G. McDonald, Stanford Jacob B. Michaelsen, UC, Santa Cruz stewart C. Myers, MIT Alfred N. Page, Washington Roger B. Upson, Minnesota James Van Horne, Stanford George von Furstenberg, Indlana Paul Wells, Illinols Richard R. West, Oregon Robert $I$. Winkler, Indiana 
Executive Committee

David Eiteman, President James Wert, Vice President Thomas E. Stitzel, Secretary-Treasurer Charles w. Haley, Editor Scott Bauman Richard V. Cotter John Herzog Vergil Miller David H. Pyle

University of California, Los Angeles University of Arizona Oregon State University University of Washington University of Virginia University of Nevada Simon Fraser University Sacramento state University of California, Berkeley

INSTITUTIONAI MEMBERS

Southern California Edison Company Weeden and Company, Inc.

National Economic Research Association
Mountain States Telephone Company California state College, Los Angeles Loyola University of Los Angeles

Copyright 1973 by the Graduate School of Business Administration, University of Washington.

The Journal of Financial and Quantitative Analysis is published in January, March, June, September, and December by the Graduate School of Business Administration, University of Washington, Seattle, Washington 98195, in conjunction with the Western Finance Association. Second-class postage paid at Seattle, Washington.

The December issue is a special issue devoted to one topic of interest to the JFQA's readership. The March issue contains selected papers, abstracts of papers, discussants' comments, and the Proceedings of the Western Finance Association meetings.

The views and opinions expressed are those of the authors and do not necessarily reflect those of the Graduate School of Business Administration of the University of Washington nor of the Western Finance Association.

For individuals, the annual subscription rate to the JFQA is $\$ 10.00$ (two-year rate, $\$ 20$; three-year rate, $\$ 28$ ); for firms or libraries, the annual rate is $\$ 15.00$ (two-year rate, $\$ 30$; three-year rate, \$40). Single copies are $\$ 3.00$, except the special issues, the price of which is $\$ 3.50$. Annual subscription rates for individuals and libraries outside the United States (except Canada) are $\$ 11.00$ for individuals (two-year rate, $\$ 22$; three-year rate, $\$ 31$ ) and $\$ 16.00$ for libraries (two-year rate, $\$ 32$; three-year rate, $\$ 43$ ). The fiscal. year of the Journal of Financial and Quantitative Analysis begins on January 1.

Manuscripts and editorial correspondence should be sent to the Managing Editor. Advertising inquiries and books for review should be addressed to the Associate Managing Editor. Correspondence dealing with subscriptions and billing should be addressed: Subscription Manager, JFQA, Mackenzie Hall DJ-10, University of Washington, Seattle, Washington 98195.

Correspondence pertaining to the Western Finance Association should be sent to Professor Thomas E. Stitzel, School of Business, Oregon State University, Corvallis, Oregon 97331. 
Optimal Equity Financing of the Corporation . . . . . . . . . . . . . . 539 clement $G$. Krouse and Wayne $Y$. Lee

Some Portfolio-Relevant Risk Characteristics of Long-Term Marketable

Securities . . . . . . . . . . . . . . . . . . . . . . . . 565 Richard W. MCEnally

An Empirical Comparison of Stochastic Dominance and Mean-Variance

Portfolio Choice Criteria . . . . . . . . . . . . . . . . . . . . . . 587 R. Burr porter

An Empirical Investigation of the Adjustment of Stock Prices to New zuarterly Earnings Information . . . . . . . . . . . . . . . . . . 609 Ronald J. Jordan

A Linear Programming Formulation of the General Portfolio Selection Problem . . . . . . . . . . . . . . . . . . . . . . . . . . . Bernell K. Stone

The Effects of Control status on Commercial Bank Profitability . . . . . 637 Alan S. MCCall and David A. Walker

Registered Bank Holding Company Acquisitions: A Cross-Section Analysis . . . . . . . . . . . . . . . . . . . . . . . . . 64 R. Charles Moyer and Edward Sussna

\section{COMMUNICATIONS}

Integer Programing in Capital Budgeting: A Note on Computational

Experience . . . . . . . . . . . . . . . . . . . . . . . . . . . Richard H. Pettway

A Note on Stock Market Indicators and Stock Prices . . . . . . . . . . . . Benton E. Gup

A Sufficient Condition for a Unique INonnegative Internal Rate of Return:

A Comment . . . . . . . . . . . . . . . . . . . . . . . . . 683 Clovis de Faro

A Note on Modeling Simple Dynamic Cash Balance Problems . . . . . . . . 685 Suresh $P$. Sethi 